\title{
Estrogen Receptor Alpha 36 Gene Knockdown Promote the Expression of NF-kB in PC12 Cells*
}

\author{
Ping Zou ${ }^{1}$, Chao $\mathrm{Qu}^{2}$, Yihui $\mathrm{Xu}^{2,3}$, Hongyan $\mathrm{Li}^{2}$, Dannv $\mathrm{Han}^{2}$, Dan $\mathrm{Shi}^{2}$, Wei Zou ${ }^{2,4 \#}$ \\ ${ }^{1}$ Teachers College, Dalian University, Dalian, China \\ ${ }^{2}$ College of Life Science, Liaoning Normal University, Dalian, China \\ ${ }^{3}$ School of Life Science, Shandong University, Jinan, China \\ ${ }^{4}$ The Research Center of Developmental and Educational Psychology, Liaoning Normal University, Dalian, China

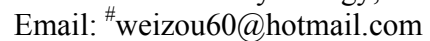

Received May 14, 2013; revised June 14, 2013; accepted July 14, 2013

Copyright (C) 2013 Ping Zou et al. This is an open access article distributed under the Creative Commons Attribution License, which permits unrestricted use, distribution, and reproduction in any medium, provided the original work is properly cited.

\begin{abstract}
The nuclear transcription factors $\kappa \mathrm{B}(\mathrm{NF}-\kappa \mathrm{B})$ is widely existed in various kinds of cell types in the nervous system and plays an important role in neuron apoptosis and neurodegenerative diseases. Estrogen receptor alpha 36 (ER- $\alpha 36$ ) is a novel variant of $\mathrm{ER} \alpha$ (as known ER- $\alpha 66$ ) which can transduce both estrogen- and antiestrogen-dependent activation of MAPK signal pathway and stimulate cell growth. Here, we aimed to detect the effect of ER- $\alpha 36$ gene silencing on the expression of NF- $\mathrm{\kappa B}$ in normal cultured $\mathrm{PC} 12$ cells and to provide an experimental foundation for understanding the function of ER- $\alpha 36$ in nerve cells. PC12 cells with ER- $\alpha 36$ expression knocked down by the shRNA method. Then Western blot and immunocytochemical staining were performed to detect the expression and translocation of NF- $\mathrm{kB}$ after transfection. The results showed that NF- $\mathrm{BB}$ expression was significantly higher comparing with the control group after transfection $(\mathrm{P}<0.01)$. Also, NF- $\kappa \mathrm{B}$ subunit entered nuclear after transfection; Immunofluorescence staining and immunocytochemical staining of PC12 cells demonstrated that ER- $\alpha 36$ was expressed mainly on the plasma membrane and on the cell nucleus membrane. These data indicate that ER- $\alpha 36$ gene silencing can increase the expression of $\mathrm{NF}-\mathrm{KB}$ and promote its nuclear translocation in PC12 cells.
\end{abstract}

Keywords: NF-kB; Estrogen Receptor Alpha 36; PC12 Cells

\section{Introduction}

Nuclear factor kappa B (NF- $\mathrm{B})$, as a dimeric transcription factor, is widely existing in neurons of central nervous system. Activated (NF-KB) controls the expression of genes that regulate a broad range of biological processes through canonical and non-canonical pathways, such as synaptic plasticity, cell injury, and the adjustment of the immune and inflammatory response factors expressions, such as cell adhesion molecules and cytokines. In the central nervous system, NF- $\mathrm{KB}$ controls inflammatory reactions and the apoptotic cell death following nerve injury [1], which plays a regulating role in the course of inflammation and immunoreaction during neuron apoptosis and neurodegenerative diseases and the change of NF- $\mathrm{KB}$ expression caused the neuron death and astrocyte activation. It is also reported that the activation

\footnotetext{
*This work was supported by the Chinese National Natural Science Foundation (No. 30970353).

\#Corresponding author.
}

of NF- $\mathrm{KB}$ and CREB is involved in the protection of chromaffin cells and the sympathoadrenal PC12 cells (an established model for the study of neuronal cell apoptosis and survival) against serum deprivation-induced apoptosis by the neuroactive steroids dehydroepiandrosterone (DHEA), its sulfate ester DHEAS and allopregnanolone (Allo) [2]. However, NF- $\kappa B$ is essential for neurosurvival as well. NF- $\mathrm{kB}$ activation is a part of recovery process that may protect neurons against oxidative-stresses or brain ischemia-induced apoptosis and neurodegeneration [3].

Recent studies show that estrogen receptor- $\alpha$ mediates the brain anti-inflammatory activity of estradiol. It has also been reported that estradiol-induced enhancement of object memory consolidation involves hippocampal extracellular signal regulated kinase activation and membrane-bound estrogen receptors [4]. ER- $\alpha 36$, as a newly discovered estrogen receptor subtype, lacks both transactivation domains and functions as a dominant-negative effector of transactivation activities of the full-length 
ER- $\alpha 66$ and ER $\beta$ [5]. ER- $\alpha 36$ primarily localizes to the cytoplasm and plasma membrane, it can transduce both estrogen-and antiestrogen-dependent activation of MAPK signal pathway, stimulating proliferation of breast cancer cells [6].

The interaction between ER- $\alpha 66$ and NF- $\kappa B$ has been studied in many kinds of cell types. ER can affect the NF- $\kappa B$ transcript activity by several aspects. It has been reported that the ER protects against debilitating effects of the inflammatory response by inhibiting the NF- $\mathrm{KB}$ in the MCF-7 breast cancer cell line. Tamoxifen treatment in ER-positive breast cancer up regulate NF- $\mathrm{KB}$ gene [7]. And the activity of NF- $\mathrm{KB}$ relies on the expression of ER in MCF-7 and HER2 cell line: the more ER expressed,

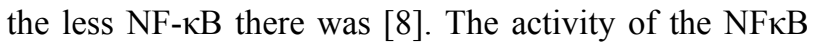
signaling cascade is associated with mammary carcinogenesis, especially tumors with an aggressive and ERnegative phenotype [9]. ER- $\alpha 36$ expression is regulated differently from ER- $\alpha 66$, consistent with the findings that ER- $\alpha 36$ is expressed in specimens from ER-negative breast cancer patients and established ER-negative breast cancer cells that lack ER- $\alpha 66$ expression [10,11]. Although the function of ER- $\alpha 36$ has been studied in cancer, to our knowledge, it has not yet been known in the nervous system. As ER- $\alpha 36$ may play important roles in these progresses, it is of great importance to detect the function of ER- $\alpha 36$ and its interaction with NF- $\mathrm{KB}$ in neuron apoptosis and neurodegenerative diseases.

\section{Results}

\subsection{The Transfection of ER- $\alpha 36$ shRNA down Regulate the Expression of ER- $\alpha 36$ in PC12 Cells (Figure 1)}

The transfection efficiency of ER- $\alpha 36$ shRNA plasmid was detected by observing the fluorescence 48 hours after transfection and it was nearly $87 \%$. ER- $\alpha 36$ expression was also detected by Western blot and the expression level of ER- $\alpha 36$ protein was suppressed by up to $25 \%$ which shows that there was high interference efficiency.

\subsection{The Down Regulation of ER- $\alpha 36$ Promote the Expressions of NF- $\mathrm{KB}$ and Related Proteins in PC12 Cells (Figure 2)}

$\mathrm{NF}-\kappa \mathrm{B}$ is widely existed in various kinds of cell types in nervous system. After transfection in PC12 cells for 48 hours, NF- $\mathrm{KB}$ was activated and had translocated from plasma to the nucleus. Compared with the control group, the expression level of NF- $\mathrm{BB}$ increased significantly after transfection. These date indicate that ER- $\alpha 36$ genesilencing can increase the expression of NF- $\mathrm{\kappa B}$ and promote its nuclear translocation in PC12 cells. The expres-
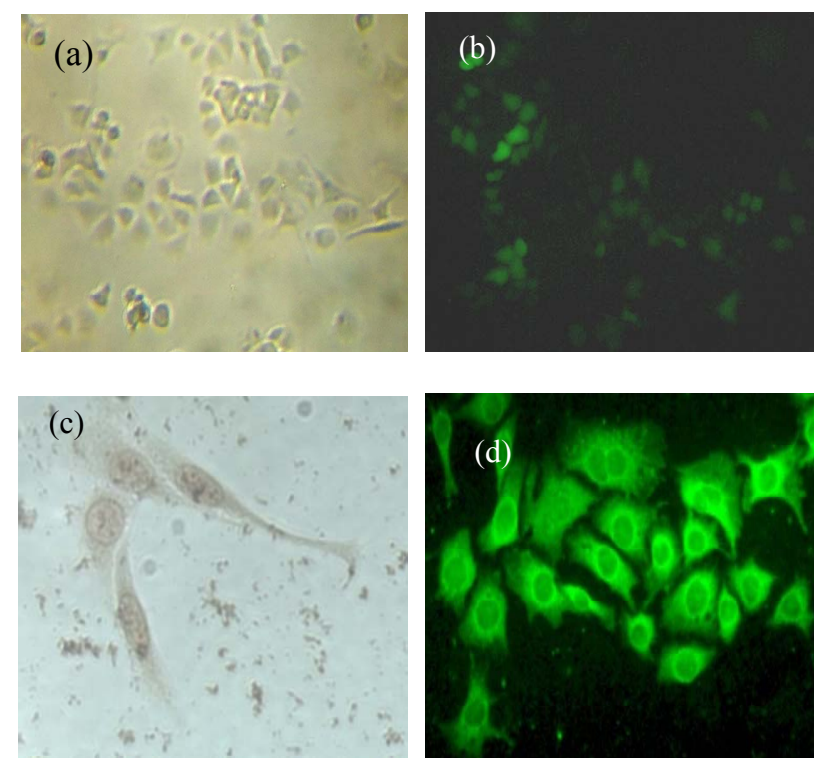

(A)

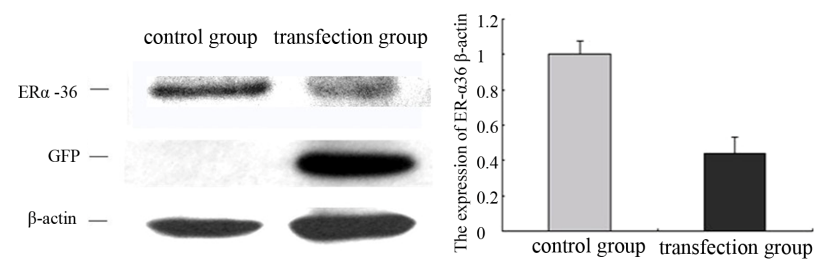

(B)

Figure 1. The transfection of ER- $\alpha 36$ shRNA down regulate the expression of ER- $\alpha 36$ in PC12 cells. (A) Control group (a) $\times 100)$. GFP protein expressions in the $\mathrm{PC} 12$ cells after transfection for 48 hours $($ b) $\times 100)$ immunocytochemical staining detection ER-a36 location in PC12 (c) $\times 400)$. Immunofluorescence staining detection ER- $\alpha 36$ location in PC12 (d) $\times 400$ ). (B) Western blot detection on ER- $\alpha 36$ expression after transfection for 48 hours in PC12 cells. Densitometric analysis of ER- $\alpha 36 / \beta$-actin. The results are presented as means \pm SEMs of three independent experiments.

sion of p-P38 and P38 were also detected by Western blot and there is a markerable increase after transfection.

\section{Discussion}

ER- $\alpha 36$ has been increasingly implicated in breast cancer cells, however, the role of ER- $\alpha 36$ in the brain has not been reported. ER- $\alpha 36$ as a newly discovered estrogen receptor subtype lacks both transcriptional activation domains of $\mathrm{ER} \alpha$ (AF1 and AF2), but retains the DNAbinding domain and partial dimerization and ligandbinding domains. It is predominantly localizes to the cytoplasm and plasma membrane and mediates the membrane-initiated estrogen signaling in breast cancer cells. We show here that ER- $\alpha 36$ expressed on the plasma membrane and cell nuclear envelope in the PC12 cells. Thus, our results reveal the difference of ER- $\alpha 36$ between PC12 cells and breast cancer cells. 

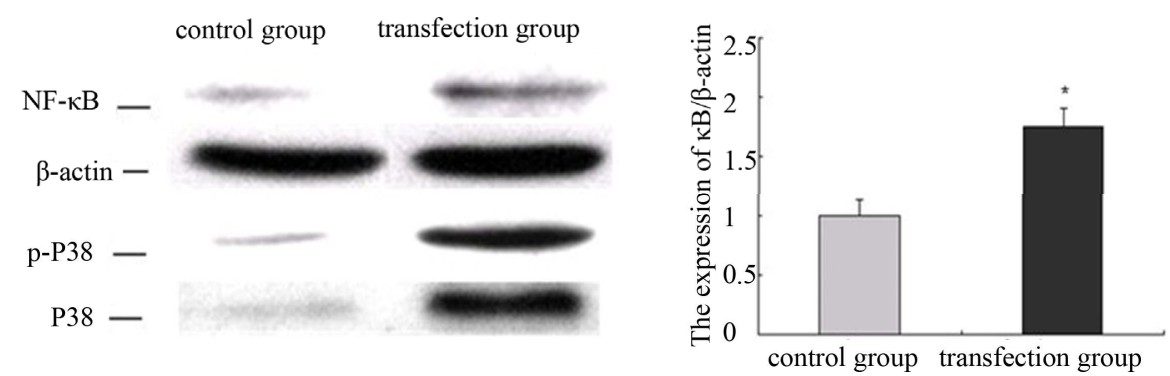

(A)

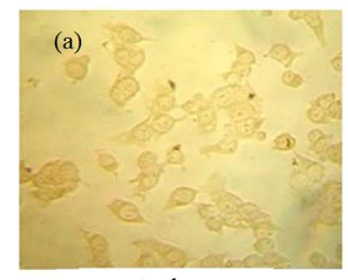

control group

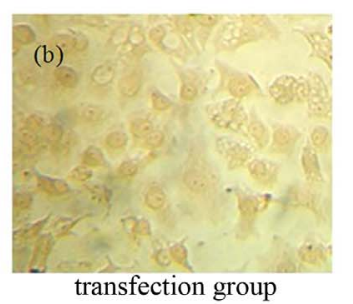

(B)

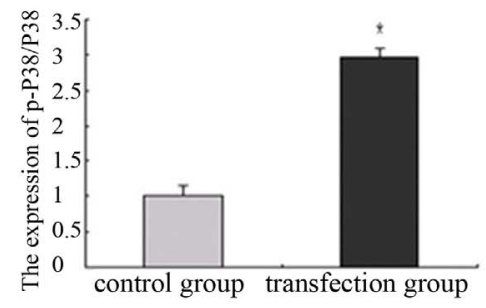

Figure 2. The down regulation of ER-a36 promote the expressions of NF-кB and related proteins in PC12 cells. (A) The expressions of NF- $\mathrm{NB}$, p-P38 and P38 were detected by western blot after transfection for 48 hours in PC12 cells. Densitometric analysis of $\mathrm{NF}-\kappa \mathrm{B} / \boldsymbol{\beta}$-actin; Densitometric analysis of $\mathrm{p}-\mathrm{P38} / \mathrm{P38}$. The results are presented as means $\pm \mathrm{SEMs}$ of three independent experiments ("significantly different from the control group); (B) Immunocytochemical staining showed that NF- $\kappa \mathrm{B}$ subunit expression and location in PC12 cells after transfection for 48 hours.

$\mathrm{NF}-\mathrm{\kappa B}$ is a transcription factor that regulates the expression of a large number of genes that are critical for the regulation of cellular process, such as inflammatory responses, apoptosis, and cell proliferation [12]. NF- $\mathrm{kB}$ pathways may promote central nervous system (CNS) cell survival through the inhibition of caspase- 1 and -3 activity [13], and NF- $\mathrm{KB}$ as key mediators of the neuroprotective against inflammatory stress in nigral dopaminergic (DA) neurons [14].

In recent studies, NF- $\kappa B$ transrepression of steroid hormone receptors has been found [15]. 17 beta-estradiol $(\mathrm{E} 2 \beta)$ treatment produced strong protective effects by reducing infarct volume, neuronal apoptosis, and inflammatory responses caused by NF- $\mathrm{KB}$ activation through estrogen receptors in transient cerebral ischemia model [16]. Several groups have reported the direct interaction between ER $\alpha$ and NF- $\mathrm{KB}$ in the nucleus of living cells [17] and a reciprocal transcription inhibition between agonist-bound ER $\alpha$ and activated NF- $\mathrm{kB}$ [18]. Previous work demonstrated that the NF- $\mathrm{kB}$ transcription factor promotes survival and chemoresistance in human breast cancer [19]. The NF-KB signaling pathways have been implicated as mediators of breast cancer drug resistance. The literature reported that ER- $\alpha 36$ existed in breast cancer patient samples and found that its expression levels were high in ER-negative tumors and low in ERpositive tumors $[20,21]$, in addition, ER- $\alpha 36$ mediates nongenomic antiestrogen signaling in ER-negative breast cancer cells such as activation of the MAPK/ERK signaling in these cells $[22,23]$, is involved in the resistance of breast cancer to endocrine therapy, for example, tamoxifen [24]. It is also been demonstrated that the nuclear translocation and activation of NF- $\mathrm{\kappa B}$ was significantly blocked by p38 MAP kinases inhibitor SB 203580 [25]. In our study, the expression of NF-KB in transfection group was increased together with the increase of p-P38 expression after ER- $\alpha 36$ gene was silenced 48 hours later. These results demonstrate that p38 MAP kinase might be upstream of NF- $\mathrm{kB}$ which plays an important role in nervous system.

In summary, we reported the function of ER- $\alpha 36$ might be associated with NF- $\mathrm{kB}$ transcription factor and showed that ER- $\alpha 36$ gene silencing promoted the expression of NF- $\mathrm{kB}$ in ER-negative PC12 cells. It's suggesting that non-genomic estrogen signaling mediated by ER$\alpha 36$ contributes to development and progression of $\mathrm{PC} 12$ cells that express NF- $\mathrm{\kappa B}$. This is the first report to our knowledge that demonstrates that ER- $\alpha 36$ gene silencing promote the expression of $\mathrm{NF}-\mathrm{\kappa B}$ in $\mathrm{PC} 12$ cells, but which kind of cross-talk is involves in this process remains to be determined.

\section{Materials and Methods}

\subsection{Chemicals and Antibodies}

All chemicals used in this study were purchased from Sigma Chemical Company (St Louis, MO). Antibodies of NF- $\mathrm{KB}, \mathrm{GFP}, \mathrm{p}-\mathrm{P} 38$ and P38 were purchased from cell signaling Company. Rabbit polyclonal anti-ER- $\alpha 36$ antibody was a gift from Dr Zhao-Yi Wang (Creighton 
University, CaliforniaPlaza, USA).

\subsection{Cell Culture and Transfections}

PC12 cells were grown in RPMI medium 1640 (Sigma) supplemented with $5 \% \mathrm{FBS}$ and $10 \% \mathrm{HS}$ at $37^{\circ} \mathrm{C}$ under a humidified 5\% $\mathrm{CO}_{2}$ atmosphere. For transient transfection experiments, $6 \times 10^{5}$ cells per well were seeded in 6well plates in $2 \mathrm{ml}$ of RPMI medium 1640 without antibiotics. Transient transfections were performed with lipidLipofectamine $^{\mathrm{TM}} 2000$ for 48 hours. Each experiment was performed on triplicate samples and repeated at least three times.

\subsection{Western Blot Analysis}

The cells were collected in ice-cold PBS, and then the cells extracts were prepared in RIPA buffer with proteinase inhibitor cocktail from Sigma (St. Louis, MO). Cell lysates were boiled with gel-loading buffer for $5 \mathrm{~min}$ at $100^{\circ} \mathrm{C}$, resolved on $10 \%$ SDS-PAGE, transferred to PVDF membrane, probed with appropriate antibodies and visualized with enhanced chemiluminescence (ECL) detection reagents (Amersham Pharmacia Biotech, Piscataway, $\mathrm{NJ})$.

\subsection{Immunocytochemistry}

Cells were fixed in $4 \%(\mathrm{w} / \mathrm{v})$ paraformaldehydein PBS ( $\mathrm{pH}$ 7.4) followed by Permeabilization in $0.2 \%(\mathrm{v} / \mathrm{v})$ Triton X-100 in PBS (PBST). Background staining was minimalized by incubating these ctionsins $50 \%(\mathrm{v} / \mathrm{v})$ ethanol, $0.9(\mathrm{v} / \mathrm{v})$ hydrogen peroxide in PBS for $30 \mathrm{~min}$ to block endogenous peroxidaseactivity. $0.9 \%$ followed by $4 \%(\mathrm{w} / \mathrm{v})$ bovine serum albumin in PBS for $1 \mathrm{~h}$ at room temperature. 1:200 dilution of the anti-NF- $\mathrm{kB}$ antibody was added to the slides and incubated for 1 hour at $37^{\circ} \mathrm{C}$. After removing unbound antibody with PBST washes, immuno reactivity was detected with a biotinylated secondary antibody followed by an avidin horseradish peroxidase complex. Immunoreactivity was visualized using a diaminobenzidine staining kit for $30 \mathrm{~min}$.

\subsection{Immunofluorescent}

Cells were plated onto laminin-coated coverslips whereas were plated onto poly-1-lysine-coated coverslips. Cells grown on cover glasses were washed twice with PBS and then fixed with $4 \%$ ice cold paraformaldehyde for $15 \mathrm{~min}$. The cover slips were washed three times with $0.1 \%$ Triton X-100 in PBS and blocked with 5\% bovine serum albumin (BSA) (Roche) in phosphate buffered saline solution for $1 \mathrm{~h}$, and after that incubated with anti-ER- $\alpha 36$ antibodies (rabbit polyclonal, 1:100, Millipore). After washing (three times for $10 \mathrm{~min}$ in PBS), cells were incubated with Rhodamine-conjugated affinipure goat anti- rabbit antibodies (1:300, Zhongshan Goldenbridge Biotechnology, China). Nuclei were stained using DAPI $(0.2$ $\mu \mathrm{g} / \mathrm{mL}$, Sigma). Fluorescence was imaged with a BioRad MRC 600 confocal imaging system. Images were acquired using a Leica TCS SP2 MultiPhoton confocal microscope.

\subsection{Statistical Analysis}

Statistical analyses were performed using SPSS statistical software. Treatment effects were analyzed using oneway analysis of variance. Significance was set at $\mathrm{P}<$ 0.05 .

\section{REFERENCES}

[1] F. Cavttaneo, G. Guerra and R. Ammendola, "Expression and Signaling of Formyl-Peptide Receptors in the Brain," Neurochemical Research, Vol. 35, No. 12, 2010, pp. 20182026. doi:10.1007/s11064-010-0301-5

[2] I. Charalampopoulos, V. I. Alexaki, C. Tsatsanis, V. Minas, E. Dermitzaki, I. Lasaridis, L. Vardouli, C. Stournaras, A. N. Margioris, E. Castanas and A. Gravanis, "Neurosteroids as Endogenous Inhibitors of Neuronal Cell Apoptosis in Aging," Annals of the New York Academy of Sciences, Vol. 1088, 2006, pp. 139-152.

doi:10.1196/annals.1366.003

[3] C. H. Nijboer, C. J. Heijnen, F. Groenendaal, M. J. May, F. van Bel and A. Kavelaars, "Strong Neuroprotection by Inhibition of NF-KappaB after Neonatal Hypoxia-Ischemia Involves Apoptotic Mechanisms but Is Independent of Cytokines," Stroke, Vol. 39, No. 7, 2008, pp. 2129 2137. doi:10.1161/STROKEAHA.107.504175

[4] S. M. Fernandez, M. C. Lewis, A. S. Pechenino, L. L. Harburger, P. T. Orr, J. E. Gresack, G. E. Schafe and K. M. Frick, "Estradiol-Induced Enhancement of Object Memory Consolidation Involves Hippocampal Extracellular Signal-Regulated Kinase Activation and MembraneBound Estrogen Receptors," The Journal of Neuroscience, Vol. 28, No. 35, 2008, pp. 8660-8667. doi:10.1523/JNEUROSCI.1968-08.2008

[5] Z. Wang, X. Zhang, P. Shen, B. W. Loggie, Y. Chang and T. F. Deuel, "Identification, Cloning, and Expression of Human Estrogen Receptor-Alpha36, a Novel Variant of Human Estrogen Receptor-Alpha66," Biochemical and Biophysical Research Communications, Vol. 336, No. 4, 2005, pp. 1023-1027. doi:10.1016/j.bbrc.2005.08.226

[6] L. M. Lee, J. Cao, H. Deng, P. Chen, Z. Gatalica and Z. Y. Wang, "ER-Alpha36, a Novel Variant of ER-Alpha, Is Expressed in ER-Positive and -Negative Human Breast Carcinomas," Anticancer Research, Vol. 28, No. 1B, 2008, pp. 479-483.

[7] C. Hicks, R. Kumar, A. Pannuti and L. Miele, "Integrative Analysis of Response to Tamoxifen Treatment in ER-Positive Breast Cancer Using GWAs Information and Transcription Profiling," Breast Cancer, Vol. 6, 2012, pp. 47-66.

[8] K. W. Nettles, G. Gil, J. Nowak, R. Métivier, V. B. 
Sharma and G. L. Greene, "CBP Is a Dosage-Dependent Regulator of Nuclear Factor-KappaB Suppression by the Estrogen Receptor," Molecular Endocrinology, Vol. 22, No. 2, 2008, pp. 263-272. doi:10.1210/me.2007-0324

[9] J. W. Antoon, M. D. White, E. M. Slaughter, J. L. Driver, H. S. Khalili, S. Elliott, C. D. Smith, M. E. Burow and B.S. Beckman, "Targeting NFKB Mediated Breast Cancer Chemoresistance through Selective Inhibition of Sphingosine Kinase-2," Cancer Biology \& Therapy, Vol. 11, No. 7, 2011, pp. 678-689. doi:10.4161/cbt.11.7.14903

[10] Y. Zhou, S. Eppenberger-Castori, C. Marx, C. Yau, G. K. Scott, U. Eppenberger and C. C. Benz, "Activation of Nuclear Faetor-KappaB (NFkappaB) Identifies a High-Risk Subset of Hormone-Dependent Breast Cancers," The International Journal of Biochemistry \& Cell Biology, Vol. 37, No. 5, 2005, pp. 1130-1144. doi:10.1016/j.biocel.2004.09.006

[11] L. Shi, B. Dong, Z. Li, Y. Lu, T. Ouyang, J. Li, T. Wang, Z. Fan, T. Fan, B. Lin, Z. Wang and Y. Xie, "Expression of ER- $(\alpha) 36$, a Novel Variant of Estrogen Receptor- $(\alpha)$, and Resistance to Tamoxifen Treatment in Breast Cancer," Journal of Clinical Oncology, Vol. 27, No. 21, 2009, pp. 3423-3429. doi:10.1200/JCO.2008.17.2254

[12] G. Zhang and S. Ghosh, "Toll-Like Receptor-Mediated NFкB Activation: A Phylogenetically Conserved Paradigm in Innate Immunity," Journal of Clinical Investigation, Vol. 107, No. 1, 2001, pp. 13-19. doi:10.1172/JCI11837

[13] A. L. Bernardino, T. A. Myers, X. Alvarez, A. Hasegawa and M. T. Philipp, "Toll-Like Receptors: Insights into Their Possible Role in the Pathogenesis of Lyme Neuroborreliosis," Infection and Immunity, Vol. 76, No. 10, 2008, pp. 4385-4395. doi:10.1128/IAI.00394-08

[14] J. K. Lee, J. Chung, K. M. Druey and M. G. Tansey, "RGS10 Exerts a Neuroprotective Role through the PKA/ c-AMP Response- Element (CREB) Pathway in Dopaminergic Neuron-Like Cells," Journal of Neurochemistry, Vol. 122, No. 2, 2012, pp. 333-343.

[15] L. I. McKay and J. A. Cidlowski, "Molecular Control of Immune/Inflammatory Responses: Interactions between Nuclear Factor-Kappa B and Steroid Receptor-Signaling Pathways," Endocrine Reviews, Vol. 20, No. 4, 1999, pp. 435-459. doi:10.1210/er.20.4.435

[16] N. Maulik, M. Sato, B. D. Price and D. K. Das, "An Essential Role of NFkappaB in Tyrosine Kinase Signaling of p38 MAP Kinase Regulation of Myocardial Adaptation to Ischemia," FEBS Letters, Vol. 429, No. 3, 1998, pp. 365-369. doi:10.1016/S0014-5793(98)00632-2
[17] I. Sarnico, A. Lanzillotta, M. Benarese, M. Alghisi, C. Baiguera, L. Battistin, P. Spano and M. Pizzi, "NF-KappaB Dimers in the Regulation of Neuronal Survival," International Review of Neurobiology, Vol. 85, 2009, pp. 351-362. doi:10.1016/S0074-7742(09)85024-1

[18] C. H. Nijboer, C. J Heijnen, F. Groenendaal, M. J. May, F. Bel and A. Kavelaars, "Strong Neuroprotection by Inhibition of NF-KappaB after Neonatal Hypoxia-Ischemia Involves Apoptotic Mechanisms but Is Independent of Cytokines," Stroke, Vol. 39, No. 7, 2008, pp. 2129-2137. doi:10.1161/STROKEAHA.107.504175

[19] C. B. Weldon, A. P. Parker, D. Patten, S. Elliott, Y. Tang, D. E. Frigo, C. M. Dugan, E. L. Coakley, N. N. Butler, J. L. Clayton, J. Alam, T. J. Curiel, B. S. Beckman, B. M. Jaffe and M. E. Burow, "Sensitization of ApoptoticallyResistant Breast Carcinoma Cells to TNF and TRAIL by Inhibition of p38 Mitogen-Activated Protein Kinase Signaling," International Journal of Oncology, Vol. 24, No. 6, 2004, pp. 1473-1480.

[20] J. Zhang, G. Li, Z. Li, X. Yu, Y. Zheng, K. Jin, H. Wang, Y. Gong, X. Sun, X. Teng, J. Cao and L. Teng, "Estrogen-Independent Effects of ER-a36 in ER-Negative Breast Cancer," Steroids, Vol. 77, No. 6, 2012, pp. 666-673. doi:10.1016/j.steroids.2012.02.013

[21] X. T. Zhang, L. Ding, L. G. Kang and Z. Y. Wang, "Involvement of ER- $\alpha 36$, Src, EGFR and STAT5 in the Biphasic Estrogen Signaling of ER-Negative Breast Cancer Cells," Oncology Reports, Vol. 27, No. 6, 2012, pp. 2057 2065.

[22] X. Zhang, L. Ding, L. Kang and Z. Y. Wang, "Estrogen Receptor-Alpha 36 Mediates Mitogenic Antiestrogen Signaling in ER-Negative Breast Cancer Cells," PLOS One, Vol. 7, No. 1, 2012, pp. e30174-30186.

[23] L. Kang, Y. Guo, X. Zhang, J. Meng and Z. Y. Wang, “A Positive Cross-Regulation of HER2 and ER- $\alpha 36$ Controls ALDH1 Positive Breast Cancer Cells," Molecular Biology, Vol. 127, No. 3-5, 2011, pp. 262-268.

[24] J. Rao, X. Jiang, Y. Wang and B. Chen, "Advances in the Understanding of the Structure and Function of ER- $\alpha 36$, a Novel Variant of Human Estrogen Receptor-Alpha," Molecular Biology, Vol. 127, No. 3-5, 2011, pp. 231-237.

[25] M. E. Quaedackers, C. E. van den Brink, P. T. van der Saag and L. G. Tertoolen, "Tertoolen LG Direct Interaction between Estrogen Receptor Alpha and NF-KappaB in the Nucleus of Living Cells," Molecular and Cellular Endocrinology, Vol. 273, No. 1-2, 2007, pp. 42-50. doi:10.1016/i.mce.2007.05.002 